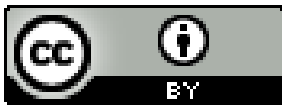

\title{
A AUTOBIOGRAFIA DE MANZANO E A CONSTRUÇÃO DO IMAGINÁRIO ABOLICIONISTA NO SÉCULO XIX
}

Resumo: A autobiografia de Juan Francisco Manzano, escrita em 1835, nos proporciona a oportunidade de perceber, mesmo com seus silêncios, a dureza da escravização durante o período de potencialização da produção de açúcar, café e algodão. A perspectiva analítica adotada é o conceito de segunda escravidão desenvolvido por Dale Tomich, que destaca as alterações sociais, culturais e econômicas nos sistemas escravistas na América durante o processo de industrialização britânica. A produção de relatos de escravizados/as é uma tradição recorrente no abolicionismo norte-americano, porém na América Latina esses relatos são raros, sendo a autobiografia de Manzano a única conhecida do gênero. Seu relato foi amplamente divulgado na Europa e apresentado na primeira World Antislavery Convention. A voz e coragem de Manzano abriram caminhos para a luta do/a negro/a pela emancipação de seu povo.

Palavras-chave: Juan Francisco Manzano; Abolicionismo; Cuba; Segunda Escravidão

\section{MANZANO'S AUTOBIOGRAPHY AND THE CONSTRUCTION OF THE ABOLITIONIST IMAGINARY IN THE 19TH CENTURY}

\begin{abstract}
The autobiography of Juan Francisco Manzano, written in 1835, gives us the opportunity to perceive, even with its silences, the hardness of slavery during the period of enhancement of sugar, coffee and cotton production. The analytical perspective adopted here is the concept of second slavery developed by Dale Tomich, which highlights the social, cultural and economic changes of the slave systems in America during the British industrialization process. The production of narratives of enslaved people is a recurring tradition in American abolitionism, but in Latin America these testimonies are rare, and Manzano's autobiography is the only known of this genre. His narrative was widely circulated in Europe and presented at the first World Slavery Convention. Manzano's voice and courage paved the way for the black people to fight for their emancipation
\end{abstract}

Keywords: Juan Francisco Manzano; Abolitionism; Cuba; Second Slavery

\footnotetext{
${ }^{1}$ Mestranda no programa PROFHISTÓRIA na Universidade Federal Fluminense; Graduada em História na Universidade Federal Fluminense e Graduada em Ciências Sociais pela Universidade do Estado do Rio de Janeiro; Professora em redes privadas no Rio de Janeiro. E-mail: analuizaoliveira92@ gmail.com
}

Revista da ABPN • v. 12, n. Ed. Especial - Caderno Temático: "Africanos, escravizados, libertos biografias, imagens e experiências atlânticas” • agosto de 2020, p. $451-478$ 


\section{O}

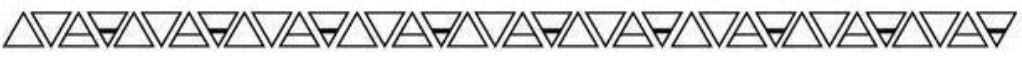

\section{LA AUTOBIOGRAFÍA DE MANZANO Y LA CONSTRUCCIÓN DEL IMAGINARIO ABOLICIONISTA EN EL SIGLO XIX}

Resumen: La autobiografía de Juan Francisco Manzano, escrita en 1835, nos brinda la oportunidad de percibir, aunque sea en sus silencios, la dureza de la esclavitud durante el periodo de potenciación de la producción de azúcar, café y algodón. Siguiendo una perspectiva analítica, el concepto de segunda esclavitud, desarrollado por Dale Tomich, destaca los cambios sociales, culturales y económicos en los sistemas esclavistas en América durante el proceso de industrialización británica. La producción de relatos de esclavizados/as es una tradición recurrente en el abolicionismo norteamericano. Sin embargo, en Latinoamérica, esos relatos son raros, puesto que la autobiografía de Manzano, es la única conocida del género. Su relato fue ampliamente difundido en Europa y presentado en la primera World Antislavery Convention. La voz y el coraje de Manzano abrieron caminos a la lucha del (de la) negro (a) por la emancipación de su pueblo.

Palabras-clave: Juan Francisco Manzano; Abolicionismo; Cuba; Segunda Esclavitud;

\section{L'AUTOBIOGRAPHIE DE MANZANO ET LA CONSTRUCTION DE L'IMAGINAIRE ABOLITIONNISTE AU XIX SIËCLE}

Résumé: L'autobiographie de Juan Francisco Manzano, écrite en 1835, nous donne la possibilité de percevoir, même avec ses silences, la dureté de l'esclavage pendant la période d'intensification de la production de sucre, de café et de coton. La perspective analytique adoptée ici est le concept de second esclavage développé par Dale Tomich, qui met en évidence les changements sociaux, culturels et économiques des systèmes esclavagistes en Amérique pendant le processus d'industrialisation britannique. La production des récits de personnes asservies est une tradition récurrente dans l'abolitionnisme américain, mais en Amérique latine, ces narratives sont rares, et l'autobiographie de Manzano est la seule connue du genre. Son récit a été largement diffusé en Europe et présenté lors de la première Convention Mondiale Antiesclavagiste. La voix et le courage de Manzano ont ouvert la voie à la lutte du peuple noir pour l'émancipation de son gens.

Mots-clés: Juan Francisco Manzano; Abolitionnisme; Cuba; Deuxième esclavage

\section{INTRODUÇÃO}

A principal fonte utilizada neste estudo será a autobiografia de Juan Francisco Manzano, traduzida para o português por Alex Castro e publicada em 2015, o texto original está disponível na Sala Cubana da Biblioteca Nacional José Martí em Havana. Escrita em 1835, sua autobiografia é um dos mais preciosos relatos sobre a escravidão

Revista da ABPN • v. 12, n. Ed. Especial - Caderno Temático: "Africanos, escravizados, libertos biografias, imagens e experiências atlânticas” • agosto de 2020, p. $451-478$ 
nas Américas, ${ }^{2}$ sendo publicada inicialmente em Londres por volta de 1840 e tendo sua publicação em Cuba, somente no século XX. Seu texto é marcado por uma escrita distante da norma culta, com "orações desconjunturadas, parágrafos ofegantes, sintaxe distorcida e ortografia idiossincrática" (Castro, 2015, p. 16). Mais do que possíveis erros de gramática, esta é a expressão de sua trajetória e resistência ao processo de escravização.

A necessidade de se construir um discurso abolicionista e uma representação da escravização no Império Espanhol fez de Manzano uma grande voz na da luta antiescravista. Porém, apesar de não poder assumir uma identidade negra explícita em suas produções, era necessário criar empatia. Manzano sabia que para ser reconhecido precisaria trabalhar o processo de identificação e de construção de uma relativa aproximação entre o leitor e o relato da vida de um escravizado. ${ }^{3}$ Não seria uma tarefa fácil, sua vida poderia estar em risco, então precisava de sutileza.

Seu relato nos permite perceber a intensa mudança nas relações sociais marcadas pela dinamização da escravização, da produção e a centralidade de áreas antes periféricas. As disputas geradas por essa centralidade levaram a uma reformulação teórica e social da escravidão cubana e ao fortalecimento de uma rede de cooperação para a manutenção do tráfico de escravizados/as e da escravização.

Durante a primeira metade do século XIX, Brasil, Cuba e EUA partilharam de duas principais questões que remetiam à política econômica global; a intensa inserção nas relações comerciais mundiais e a constante pressão abolicionista que ganhava cada vez mais força na Europa e nas colônias. Essa relação de complementaridade entre capitalismo e escravidão, que permitiu o surgimento de uma nova forma de capitalismo, foi responsável pela alteração da dinâmica social nas colônias na América. A demanda por commodities levou a uma escala de escravização nunca antes vista, que deixou suas sequelas até os dias de hoje em todo o mundo.

\footnotetext{
2 Agradeço ao Professor Dro Leonardo Marques (Universidade Federal Fluminense) pelas indicações bibliográficas, correções e colaboração na elaboração deste trabalho.

${ }^{3}$ Para compreender esse processo, Foucault apresenta duas formas de escrita de si e a correspondência adquire um maior papel no processo de formação de identidades ao fazer 'o escritor 'presente' àquele a que a dirige. E presente não apenas pelas informações que lhe dá acerca da sua vida, das suas atividades, dos seus sucessos e fracassos, das suas venturas ou infortúnios, presente de uma espécie de presença imediata e quase física".

FOUCAULT, Michel. A escrita de si. In: O que é um autor? Lisboa: Passagens. 1992. pp. 129-160.
}

Revista da ABPN • v. 12, n. Ed. Especial - Caderno Temático: "Africanos, escravizados, libertos biografias, imagens e experiências atlânticas” • agosto de 2020, p. $451-478$ 
As trajetórias de Cuba, Brasil e Estados Unidos se uniram na construção de um projeto político, social e econômico de manutenção do tráfico de escravizados/as e da escravização, permitindo sua centralidade comercial durante o século XIX. As estratégias eram distintas mas tinham o mesmo propósito, e em Cuba vigorou o isolamento e a autoridade do Capitão General, ${ }^{4}$ com o estabelecimento do Regime de faculdades onímodas, ${ }^{5}$ concentrando nas mãos do Capitão General os poderes políticos e militares, com a responsabilidade de prezar pela manutenção da ordem social escravista e pela repressão e isolamento da ilha frente aos ideais liberais.

Além da intensa repressão à imprensa e o aumento do trabalho escravo, a racialização das sociedades escravistas foi utilizada como forma de manutenção de privilégios e controle social. O processo de racialização já era uma realidade antes mesmo do surgimento de teorias sociais de diferenciação e evolução das raças. Amplamente utilizado em Cuba, o racismo foi responsável pela repressão, violência e silenciamento de corpos negros, fossem eles escravizados/as ou não. Manzano, apesar de ter uma trajetória diferenciada, nos apresenta nas sutilezas de seu relato a voracidade das sociedades escravistas, violência física, intelectual e epistêmica. Das diversas formas de violência sofridas por Manzano a violência epistêmica pode se perceber na construção de seu texto. Nas constantes cartas trocadas por Manzano e Del Monte, ${ }^{6}$ podemos perceber como seu discurso precisava seguir um padrão estético e gramatical das elites para poder estar presente naquele meio. Nas cartas trocadas, a influência e as delimitações estabelecidas por Del Monte se percebem como mais uma tentativa de silenciar o que não se quer ser ouvido em uma sociedade escravista. Com o devido cuidado para não produzir

\footnotetext{
${ }^{4}$ As principais funç̃̃es do capitão general estavam relacionadas ao controle do comércio de escravos e a garantia de ordem social na colônia.

BERBEL, Márcia; MARQUESE, Rafael; PARRON, Tâmis. Escravidão e política: Brasil e Cuba, 1790 1850. São Paulo, 2009.

${ }^{5}$ Para garantir a estabilidade política e a posse da colônia após as perdas com as independências, a Espanha cedeu às pressões conservadoras na colônia e permitiu o estabelecimento de um estado de exceção sempre que fosse necessário para garantir a ordem. Conhecido como Regime de faculdades onímodas, essa nova forma de organização social dava plenos poderes a um único homem permitindo a restrição de liberdades até mesmo de membros influentes da sociedade, além de permitir, em alguns casos, o estabelecimento de regras locais dissidentes da ordem metropolitana.

BERBEL, Márcia; MARQUESE, Rafael; PARRON, Tâmis. Escravidão e política: Brasil e Cuba, 1790 1850. São Paulo, 2009.

${ }^{6}$ Seu principal patrocinador, membro da elite cubana
}

Revista da ABPN • v. 12, n. Ed. Especial - Caderno Temático: "Africanos, escravizados, libertos biografias, imagens e experiências atlânticas” • agosto de 2020, p. $451-478$ 
anacronismos, podemos deixar o questionamento, se uma forma de escrita que não segue os padrões das elites letradas não seria por si só uma manifestação da resistência negra.

A trajetória de Manzano após a escrita de sua autobiografia, foi marcada pelo envolvimento direto na luta abolicionista articulada junto à elite antiescravista internacional, tendo, por exemplo, importante papel no desenvolvimento da Conspiração de la Escalera, ${ }^{7}$ sofrendo por isso duras repressões. Os limites impostos pelo Regime de faculdades onímodas foram representativos dos embates provocados pela Segunda Escravidão e por meio da análise de sua trajetória podemos explorar seu sucesso como abolicionista e as limitações impostas pela articulação pró-escravista no oitocentos.

\section{JUAN FRANCISCO MANZANO}

Juan Francisco Manzano nasceu em Havana no ano de 1797; publicou diversos poemas antes de escrever sua autobiografia na década de 1830. Filho de María del Pilar Manzano e Toribio de Castro, sua vida foi amplamente utilizada para fortalecer o movimento abolicionista no século XIX. Sua autobiografia circulou clandestinamente em Cuba e foi traduzida no ano de 1840 para o inglês por Richard Madden e para o francês por Victor Schoelcher, vindo a ganhar sua primeira publicação em Cuba apenas em 1937, por José Luciano Franco e Emilio Roig de Leuchsenring.

Sua primeira dona, ${ }^{8}$ Beatriz de Jústiz y Zayas, Marquesa Jústiz de Santa Ana (1733-1803), foi uma grande escritora cubana nos fins do século XVIII. Um de seus textos mais notórios foi uma carta dirigida a Carlos III relatando e questionando a postura do Império espanhol diante da invasão inglesa em $1762,{ }^{9}$ que como parte da elite comercial

\footnotetext{
${ }^{7}$ Em resposta às revoltas em Matanzas, o novo capitão general Leopoldo O’Donnell reprimiu radicalmente as revoltas na província. Foram estabelecidos processos extrajudiciais para encontrar suspeitos e entender suas intenções, foram torturadas e presas aproximadamente três mil pessoas, essa reação ficou conhecida como Conspiración de la Escalera. Manzano foi um dos condenados junto com Del monte. Segundo as análises de Robert Paquette, essa era provavelmente uma "revolução em gestação" que uniu crioulos liberais, pardos livres e escravizados com ideias de independência e pela abolição da escravidão. A intensa repressão precisava separar esses "três grupos sociais em movimento ascendente de contestação" e cuidar para fechar qualquer brecha acessível a libertos.

BERBEL, Márcia; MARQUESE, Rafael; PARRON, Tâmis. Escravidão e política: Brasil e Cuba, 1790 1850. São Paulo, 2009.

${ }^{8}$ Utilizarei o termo "dona/dono", "senhor e senhora", pois é assim que Manzano identifica esse grupo social. Seria necessário repensar essas terminologias utilizando as discussões sobre branquitude e escrita não colonial.

9 "No dia 22 de junho, os ingleses conquistaram El Morro (uma das principais fortificações da cidade) por meio da ação conjunta entre um bombardeio naval e um ataque terrestre. Uma semana depois, eles
}

Revista da ABPN • v. 12, n. Ed. Especial - Caderno Temático: "Africanos, escravizados, libertos biografias, imagens e experiências atlânticas” • agosto de 2020, p. $451-478$ 
que não via na ampliação da escravidão a melhor forma para alavancar Cuba, para ela a centralização vinculada ao setor açucareiro, foi em grande parte causada por esse episódio. ${ }^{10}$

A Senhora Dona Beatriz de Jústiz, Marquesa Jústiz de Santa Ana, Esposa do Senhor Dom Juan Manzano, gostava de pegar as crioulas mais bonitas, quando tinham entre dez e onze anos, dar-lhes uma educação de acordo com sua classe e condição [...] Entre as escolhidas, estava uma Maria del Pilar Manzano, minha mãe, que, entre as mucamas da velhice da Senhora Marquesa Jústiz, era uma das criadas de distinção ou de estimação (Castro, 2015, p. 31)

A relação com seus donos era marcada por conflitos, submissão e um paternalismo que perpassa as mudanças da escravização cubana no início do século XIX. A família pertencia à elite crioula cubana e detinha diversas propriedades, dentre elas a fazenda El Molino, local onde Manzano sofreu suas piores dores. Após a morte de sua primeira dona, ele se torna propriedade da Marquesa de Prado Ameno.

Sua mãe havia se casado com Toribio de Castro que tinha a função de criado-mor. Porém não lhe foi concedida a liberdade, como ocorreu com as outras escravizadas ao casar, e conforme argumenta Manzano, talvez seja devido a redução do número de escravos na casa. A descrição de sua família não tem muitos detalhes, sabemos que sua mãe prestava os serviços domésticos para sua dona como mucama e que seu pai além de criado-mor, também era músico, uma família em uma posição diferente da estabelecida com os/as escravizados/as que trabalhavam fora das casas e no campo. Seus irmãos são citados poucas vezes em seu relato, além de demonstrar uma relação distante diante dos/as outros/as escravizados/as. Sendo um fruto da própria dissimulação causada e fomentada pelos senhores, entre escravizados/as crioulos/as e africanos/as e uma tentativa de

conseguiram tomar a Plaza Mayor e todos os navios que estavam no porto. Ao que tudo indica, os colonos ainda ofereceram resistência por mais 10 dias, mas com pouca possibilidade de vitória pois, além da superioridade bélica, os ingleses haviam dominado a Zanja, principal fonte de água potável da cidade. Sem escolha, os habitantes de Havana se renderam no dia 12 de agosto de 1762".

Lopes dos Santos, Ynaê. La Habana Bourbônica. Reforma ilustrada e escravidão em Havana (1763-1790). Revista de Indias, LXXVII/269. Madrid, 2017

${ }^{10}$ A invasão inglesa em Havana tem sido alvo de análises pela historiografia cubana através de autores como, por exemplo, Gustavo Placer e Elena Schneider, que relacionam o evento à um dos principais fatores que alteraram a dinâmica econômica e a estrutura social na região, apesar de seu curto tempo de duração. No ano seguinte, com a resolução do tratado de Paris (1763) a espanha retomava seu domínio.

Revista da ABPN • v. 12, n. Ed. Especial - Caderno Temático: "Africanos, escravizados, libertos biografias, imagens e experiências atlânticas” • agosto de 2020, p. $451-478$ 
Manzano de se aproximar das elites, distanciando-se do grupo marginalizado, em uma tentativa de validar e dar maior sustentação ao seu discurso.

A figura benevolente de sua dona não poderia ser questionada por não conceder a liberdade a sua mãe, mesmo nos apresentando algumas sutis referências de que esse relacionamento não era sempre tão benevolente, Manzano teria que lidar com as consequências de um discurso inflamado e revelador em um ambiente hostil.

Ter família em uma condição de escravização foi uma característica negada pela historiografia, percebendo a moradia escrava como um lugar de desencontro, conflito e dor. Os estudos realizados a partir da década de 1990, incentivados por pressões populares e movimentos sociais, passam a perceber as diversas complexidades da escravidão e as diversas formas de resistência e direitos costumeiros conquistados pelos grupos escravizados e livres. A família escrava, principalmente com o trabalho de Robert Slenes (Slenes, 1997), passou a ser percebida em seu caráter dicotômico de coerção e criação de identidades. A família, apesar de ser utilizada como um instrumento de coação e coerção, dava ao/a escravizado/a uma base forte de autonomia para que "o grupo escravo também desfrute de uma experiência em comum e de instituições, inclusive familiares, que incentivam uma identidade própria" (Slenes, 1997, p. 236).

Segundo Slenes, os/as senhores/as de escravos/as fomentam de certo modo a formação da família entre os grupos escravizados. As famílias agem como forma de coação e ameaça no caso de fugas e motins, criando ao mesmo tempo uma rede de cooperação e aprisionamento de dependência com o local. Além da família, uma estratégia amplamente utilizada pelos/as senhores/as é a criação de rixas e diferenciação entre os/as escravizados/as, seja entre os/as escravizados/as da casa e o do campo ou entre escravizados/as nascidos na América e africanos/as. Criando "um sistema diferencial de incentivos no intuito de tornar os cativos dependentes e reféns de suas próprias solidariedades e projetos domésticos” (Slenes, 1997, p. 237). Essa relação aparece diversas vezes em seu relato ao se distinguir dos/as outros/as escravizados/as por seus talentos e ao ser proibido por sua dona e por seus pais de manter relações de afeto com os/as negros/as que trabalhavam na fazenda.

Revista da ABPN • v. 12, n. Ed. Especial - Caderno Temático: "Africanos, escravizados, libertos biografias, imagens e experiências atlânticas” • agosto de 2020, p. $451-478$ 
Meu pai tinha altivez e, em casa, nunca permitiu intrigas, nem que seus filhos brincassem com os negrinhos da fazenda. Minha mãe morava com ele e seus filhos, pelo que não éramos muito benquistos (Castro, 2015, p. 34).

Slenes sugere que os/as escravizados/as tecem laços de ajuda mútua dentro da senzala, incluindo cativos/as, que detinham algum recurso, ou libertos/as. A escolha para o compadrio formava ao mesmo tempo uma rede de solidariedade e um lugar de exclusão. Não só as solidariedades no apadrinhamento geram essa exclusão e diferenciação, mas a forma de distribuição do paternalismo e da benevolência gerava uma diferenciação na construção de laços e na vida cotidiana dos/as escravizados/as. Os/as cativos/as 'protegidos/as' por seus/suas senhores/as escravocratas, como no caso de Manzano, aprendem a jogar com as brechas conquistadas para conseguir maior autonomia e em alguns casos, a liberdade.

A questão do apadrinhamento aparece diversas vezes em seu relato, ele não deixa claro em seu texto a origem de seus padrinhos, no entanto ao afirmar que sua madrinha ficou responsável por sua criação quando estava próximo de completar dez anos e que seu padrinho, Javier Calvo, e seu pai, Toríbio de Castro, lhe ensinaram o ofício de alfaiate, comum entre os negros, e o levava para seus exercícios militares, seria difícil lhes atribuir uma origem branca. "Minha ama foi se desapegando de mim para colocar-me em um ofício, como de fato se verificou. Tendo uns dez anos, me puseram de pupilo com meus padrinhos, já tomando as primeiras lições de alfaiate por meu pai” (Castro, 2015, p. 34). Após a morte de sua primeira dona, continuou por um tempo na casa de sua madrinha exercendo seu ofício e frequentando os exercícios militares com seu padrinho.

Os batalhões negros eram espaços de convivência e de articulação com a sociedade civil. Criado em Havana no contexto das reformas bourbônicas em 1763, era formado por homens livres de cor e teve papel de destaque nos conflitos coloniais. O crescente medo da revolução de São Domingos e as demandas por melhores soldos e postos de comando fez com que seus benefícios fossem restringidos ainda mais (Berbel, Marquese e Paron, 2009, p. 126). A temática dos batalhões negros foi debatida na sociedade cubana e Francisco de Arango y Parreño, representante político cubano, “defendeu a desmobilização progressiva dos batalhões de pardos e morenos como meio de garantir a segurança interna da ilha diante da massa de escravos africanos que seriam

Revista da ABPN • v. 12, n. Ed. Especial - Caderno Temático: "Africanos, escravizados, libertos biografias, imagens e experiências atlânticas” • agosto de 2020, p. $451-478$ 
doravante introduzidos" (Berbel, Marquese e Paron, 2009, p. 126). Com o fim da Conspiração de Escalera, os batalhões negros foram proibidos.

Sua trajetória de vida se passa em grande parte no engenho El Molino que pertencia à família que detinha sua propriedade e por um breve período no engenho de San Miguel, ambos situados em Matanzas. As cidades de Matanzas e Havana passam durante o século XIX por grandes transformações em sua estrutura econômica e cultural.

Manzano realiza uma tentativa de organizar a família a que pertencia, talvez em uma estratégia para situar o autor contemporâneo e também para legitimar seu discurso, incluindo nomes como o de Condessa de Buena Vista, Marquesa de Prado Ameno, Dom manuel de Cárdenas y Manzano, Dom Nicolás e Dom Manuel O’Reilly. Mapear as figuras que passam por sua vida e realizar um mapeamento intelectual, pode se revelar de extrema importância para entender sua relação com a elite branca cubana e as tensões provocadas pela transgressão de sua posição na sociedade. Conseguiremos analisar aqui algumas dessas figuras em uma tentativa de tecer as redes e relações sociais partilhadas por Manzano.

O silêncio evidente em diversos trechos de sua história nos mostra os perigos e ameaças constantes à vida de um negro escravizado nas sociedades escravistas, seja pela presença do filho da Marquesa de Prado Ameno, uma antiga proprietária, entre os patrocinadores de seu relato, ou por ser um negro escravizado que desafiava toda a estrutura da sociedade escravista cubana. Para Manzano, escrever representava um ato de liberdade e ao mesmo tempo de dominação, reivindicação e também humilhação. ${ }^{11}$ Sua posição como um homem negro escravizado e escritor desafiava os limites de uma sociedade escravista no século XIX, ao mesmo tempo em que joga de forma estratégica com as brechas e o apoio da elite literária e abolicionista.

\section{A CONSTRUÇÃO DE JUAN FRANCISCO MANZANO COMO INTELECTUAL}

\footnotetext{
11 Tradução livre: El acto de escritura representa para Manzano un acto de libertad y al mismo tiempo de subyugación, de reivindicación pero también de humillación.

MILLER, Marilyn. Rebeldía narrativa, resistência poética y expresión “libre” en Juan Francisco Manzano. Revista Iberoamericana, Vol. LXXI, Núm. 211, Abril-Junio 2005, p. 429
}

Revista da ABPN • v. 12, n. Ed. Especial - Caderno Temático: "Africanos, escravizados, libertos biografias, imagens e experiências atlânticas" • agosto de 2020, p. $451-478$ 
Pensar a trajetória de Juan Francisco Manzano apenas sob a perspectiva da vida de um escravizado, é manter o discurso colonialista, que retira a humanidade de escravizados/as desde o início do processo da diáspora. As diversas formas de intelectualidade foram negadas aos corpos negros e recuperar essa capacidade intelectual através do relato de Manzano, é demonstrar que antes de seu corpo ser reduzido à categoria de 'escravo', ele é um poeta, escritor e pensador.

Petrônio Domingues (Domingues, 2018) nos apresenta em seu texto uma definição de intelectualidade, que foge a visão conceitual de uma formação específica, geralmente vinculada as elites. Uma definição mais abrangente de intelectualidade fundamenta que,

os intelectuais são fruto de um processo de formação e aprendizado, sempre atuando em conexão com outros atores sociais e organizações, intelectuais ou não, e forjando perspectivas, narrativas e projetos no emaranhado entre o cultural e o político. Nessa acepção, o conceito de intelectual é, como todos os conceitos políticos e sociais, fluido e polissêmico (Domingues, 2018, p. 5)

São encontradas algumas questões que Manzano dá maior destaque na construção de seu relato: sua relação com a escrita; sua relação com as elites e familiares; os castigos corporais sofridos e a questão da liberdade.

Sua relação com as elites fica clara ao se perceber as articulações que realiza entre sua vida e as constantes referências a casamentos e a relações de benevolência de seus/suas senhores/as. Uma das muitas referências que faz a esse apadrinhamento pelas elites se dá quando narra o episódio de seu batismo afirmando que "foi à igreja envolto no mandrião com que foi batizada a Senhora Dona Beatriz de Cárdenas y Manzano, celebrando-se com a harpa tocada por meu pai, e com música de clarineta e flauta." (Castro, 2015, p. 34). Sua relação com sua primeira dona, Beatriz de Cárdenas y Manzano é descrita por ele de forma complexa, pois ao mesmo tempo em que se tornava uma relação de afeto, era vista também como uma relação de posse em que sua mãe foi privada de seus direitos, ao se tornar o protegido de sua senhora. Uma relação de posse, benevolência, porém que não deixava Manzano esquecer qual era seu lugar social, pois "para onde fosse ela, ia eu, como um cachorrinho, com meus bracinhos cruzados" (Castro, 2015, p. 32).

Revista da ABPN • v. 12, n. Ed. Especial - Caderno Temático: "Africanos, escravizados, libertos biografias, imagens e experiências atlânticas” • agosto de 2020, p. $451-478$ 
Conta que na ocasião de seu batismo, como presente, sua dona fixou em trezentos pesos cada um a alforria de seus pais. "Quis minha sinhá marcar este dia com um de seus arroubos de generosidade, coartando meus pais e deixando-os em trezentos pesos cada um, eu deveria ter sido tão feliz, mas que seja" (Castro, 2015, p. 34). Ao estabelecer um valor para a conquista da alforria, a liberdade aparentava estar cada vez mais próxima, os/as escravizados/as poderiam pagar em prestações o valor estipulado por seu/sua dono/a. Porém essa realidade se tornava na prática social extremamente difícil de se cumprir. Muitos/as escravizados/as morriam antes de terminar de pagar as prestações, além do acesso a renda ser restrito. O valor atribuído a seus pais era um valor relativamente baixo em relação aos talentos e funções que exerciam na casa, o pai de Manzano além de criado-mor também era músico. Ainda sobre a questão da liberdade, Manzano lembra o caso em que sua primeira dona Beatriz de Jústiz, assinou um acordo com seus pais para conceder a liberdade ao próximo ventre de sua mãe, tendo nascido gêmeos, seu pai teve de recorrer à justiça para fazer valer seu direito.

Passado um tempo Manzano foi enviado à casa de sua nova dona, a Marquesa de Prado Ameno de quem se tornou 'pupilo'.

\begin{abstract}
logo me esqueci de minha antiga vida recolhida. Os teatros, passeios, saraus, bailes até de manhã e outras romarias me tornaram a vida alegre e nada sentia ter deixado a casa de minha madrinha, onde apenas rezava, costurava com meu padrinho e, aos domingos, brincava e falava com alguns bonecos, sempre sozinho (Castro, 2015, p. 37).
\end{abstract}

Juan Francisco Manzano no processo de construção de seu relato oculta e seleciona os acontecimentos de sua vida que considera relevante para os objetivos da elite literária que patrocinou sua escrita. As relações com seus senhores e com membros da elite são sempre suavizadas e marcadas pela benevolência, até mesmo em sua relação com a Marquesa de Prado Ameno. Apesar dos silenciamentos em relação aos conflitos inerentes à vida de um escravizado, os constantes castigos aparecem em seu relato. Uma das características principais que deixa em evidência em seu texto é o caráter arbitrário e banal da violência contra os cativos. Seus "delitos comuns eram não atender à primeira vez que $o$ chamassem ou deixar de ouvir alguma palavra, no momento de alguém lhe dava

Revista da ABPN • v. 12, n. Ed. Especial - Caderno Temático: "Africanos, escravizados, libertos biografias, imagens e experiências atlânticas” • agosto de 2020, p. $451-478$ 
um recado" (Castro, 2015, p. 39). A violência arbitrária era uma demonstração do poder da sociedade escravista perante o corpo do/a escravizado/a.

Conta que "por qualquer travessura própria de rapaz, sofria eu trancado em uma carvoeira de chão de terra, por mais de vinte e quatro horas" (Castro, 2015, p. 37). Ele traz diversos casos em que por pequenas travessuras, acusações ou pela simples desconfiança por parte de seus senhores, lhe eram concedidos castigos brutais e desproporcionais ao ato pelo qual era castigado. Era confinado por muitas vezes a "uma latrina infecta, úmida e sempre pestífera, do qual só estava separado por umas paredes cheias de furos, ninho de ratazanas disformes que, sem cessar, me passavam por cima" (Castro, 2015, p. 38). Nestes castigos, ele ressalta a figura do senhor Dom Nicolás e de seus irmãos que por bondade lhe davam água e um pouco de pão. Nicolás era uma das figuras presentes nos saraus literários de que participava e o qual encomendou seu relato. Cabe perceber até que ponto ressaltar essa bondade não era uma estratégia de aproximação com as elites e também uma forma de sobrevivência.

Manzano atribui seu aspecto fraco e pálido desde os 14 anos ao amargor dos constantes castigos e do medo de estar constantemente alerta para tentar evitar novos castigos.

\begin{abstract}
Como a melancolia estava já instalada em minha alma e havia tomado em meu físico uma parte de minha existência, eu me sentava embaixo de uma guaxiúma, cujas raízes formavam uma espécie de pedestal, e me alegrava compondo alguns versos de memória, todos eram sempre tristes, que eu não escrevia por ignorar esse ramo. Por isso sempre trazia um caderno de versos na memória e, por qualquer coisa, improvisava (Castro, 2015, p. 40)
\end{abstract}

Manzano conta um caso de castigo durante sua juventude. Lembra que partiam para Matanzas quando começaram a circular as moedas do monarca Fernando VII, na ocasião sua dona tinha lhe presenteado com uma das moedas, assim como o fez também Dom Nicolás. Manzano deu uma das moedas a um mendigo pedindo esmolas e ao chegar em casa e sua sinhá ter percebido a existência de uma moeda em sua posse, o acusou de roubo. Apesar de argumentar que ela mesma tinha lhe dado a moeda, foi castigado e enviado para o Engenho de San Miguel com as recomendações ao capataz de dar "vinte

Revista da ABPN • v. 12, n. Ed. Especial - Caderno Temático: "Africanos, escravizados, libertos biografias, imagens e experiências atlânticas” • agosto de 2020, p. $451-478$ 
e cinco chibatadas de manhã e outras tantas à tarde, pelo espaço de nove dias, trabalhar no campo do pôr do sol ao nascer do sol" (Castro, 2015, p. 53).

Manzano destaca um castigo especialmente cruel e também com motivação duvidosa. Na ocasião conta que sua sinhá deu falta de um frango após a entrega de uma certa quantidade. A acusação caiu sobre ele e mesmo argumentando que não tivera contato com o animal, foi castigado. Desta vez seu castigo foi ser amarrado e obrigado a correr na frente de um cavalo.

Já tínhamos nos distanciado como um quilômetro quando, fadigado de correr à frente do cavalo, dei um tropeção e caí. Nem bem havia tocado o chão quando dois cães, ou feras, que nos seguiam se jogaram em cima de mim. Um deles, enfiando quase todo o meu queixo esquerdo em sua boca, me atravessou o incisivo até dar com meu molar. $\mathrm{O}$ outro me perfurou uma coxa e a panturrilha esquerda, tudo com a maior voracidade e presteza, cujas cicatrizes estão perpétuas, apesar dos vinte e quatro anos que se passaram sobre elas (Castro, 2015, p. 62)

Esse não seria o fim de seu castigo. sofreu vinte e cinco açoites durante nove dias até que se descobriu que o frango na realidade foi feito de jantar na mesma noite em que chegou preparado pelo mordomo.

As constantes e severas punições e a morte de sua mãe fez com que perdesse

o agradável sonho de minha esperança, eu já não era um escravo fiel. De manso cordeiro, me tornei a criatura mais desdenhosa e não queria ver ninguém que me falasse sobre esse assunto. Quisera ter asas para desaparecer, transplantando-me para Havana. Embotaram-se todos os sentidos de gratidão e só pensava em minha fuga (Castro, 2015, p. 77)

Com as constantes e severas punições, a ideia de protagonizar uma fuga veio à mente diversas vezes. No entanto com o período de calmaria que veio logo a seguir, sua esperança de conseguir a liberdade através de sua dona se tornava cada vez maior. Se aproveitando desse momento, tratou de aprender muitos ofícios se preparando para a liberdade que parecia estar cada vez mais próxima. "Desde que me enchi, ou me encheram, da ideia de que logo seria livre, tratei de me encher de muitas habilidades" (Castro, 2015, p. 80), escrevendo muitos cadernos de poesias e também se dedicando a tarefas que pudessem lhe trazer alguma renda quando atingisse a liberdade.

Revista da ABPN • v. 12, n. Ed. Especial - Caderno Temático: "Africanos, escravizados, libertos biografias, imagens e experiências atlânticas” • agosto de 2020, p. $451-478$ 
Esses períodos de calmaria oscilavam com os castigos severos transformando sua relação com a Marquesa de Prado Ameno cheia de complexidades. Ao mesmo tempo que o medo e a amargura se encontravam em seu coração, em períodos de calmaria ele se enchia de esperanças de liberdade e voltava a amar e respeitar sua dona como uma mãe. Ressaltar seus verdadeiros sentimentos em um relato que seria lido e apropriado pela elite branca cubana, em que um dos seus ávidos leitores era o próprio Nicolás, filho da Marquesa de Prado Ameno, pode nos deixar dúvidas sobre seus sentimentos e angústias.

Segundo Sidney Chalhoub (Chalhoub, 1988), as relações estabelecidas em uma sociedade escravista não podem ser vistas apenas como relações dicotômicas entre resistência, sobrevivência, introjeção de valores senhoriais e acomodação. Em uma mesma pessoa podem existir e coexistir questões conflitantes, retirando o argumento de coisificação do escravizado.

Porém, a sorte de Manzano mudou; com a doença da Marquesa de Prado Ameno, as torturas e a vida de medo constante voltaram à tona. "Esse tratamento me mostrou quantos cálculos errados eu havia construído sobre minha sorte desenganado de que a liberdade era apenas um sonho [...], me acometeu de novo a idéia de me ver em Havana" (Castro, 2015, p. 84). Novamente vemos a ideia de organizar uma fuga.

Manzano conta sobre uma conversa que teve na ocasião de um de seus castigos na fazenda com outro escravizado em que ele incentiva sua fuga e afirma que o tratamento que está recebendo não deve ser o tratamento dado a um/a escravizado/a e que se fosse até a justiça relatar os horrores que vinha sofrendo ganharia a liberdade. "Ele me falou desse modo por muito tempo, concluindo por me dizer que, se eu chegasse ao tribunal do capitão-geral fazendo um relato completo de tudo que me acontecia, poderia terminar livre" (Castro, 2015, p. 84). Recorrer à justiça não era tão incomum aos/as escravizados/as, que recorriam muitas vezes baseados no direito costumeiro conquistado nas relações diárias, realizando cotidianamente negociações a partir de suas concepções de justiça e injustiça.

Outro caso de intervenção a partir da justiça, que Manzano traz em seu relato, é a promessa feita por sua primeira dona Beatriz de Justiz, de liberdade ao próximo filho que sua mãe viesse a ter. Ao nascerem gêmeos, a promessa foi contestada e seu pai teve de recorrer à justiça para garantir a liberdade para seus dois filhos. Essa relação entre

Revista da ABPN • v. 12, n. Ed. Especial - Caderno Temático: "Africanos, escravizados, libertos biografias, imagens e experiências atlânticas” • agosto de 2020, p. $451-478$ 
propriedade e liberdade deixam o poder da liberdade nas mãos dos/as senhores/as, passando pela submissão e obediência, claramente em um processo de controle social que salvo exceções não passam pelo poder público, mas se concentram no poder privado. A possibilidade de revogação seria um forte reforço à ideologia da relação entre senhores/as e escravos/as, como caracterizado por paternalismo, dependência e subordinação, traços que não se esgotariam com a ocorrência da alforria (Chalhoub, 1988). E, durante o século XIX, as relações escravistas foram cada vez mais sendo desvinculadas do poder senhorial, enfraquecendo e transferindo o poder de decisão para o Estado.

Segundo Secreto (Secreto, 2011), a esperança de liberdade surge com as revoluções e independências na América hispânica e são ampliadas em Cuba pelas discussões nas cortes de Cádiz entre 1810 e 1814. Essas novas repúblicas inspiradas em ideias liberais caíam em um paradoxo entre a liberdade e a escravidão, abrindo caminho para a contestação da estrutura da sociedade. Os discursos sobre os direitos naturais de liberdade e a propriedade passam a se enfrentar tanto nas cadeiras políticas quanto nas ruas. Neste contexto de contradição, muitos/as escravizados/as utilizaram as legislações das siete partidas para reivindicar sua liberdade individual, mantendo, porém, um silenciamento sobre a liberdade total e coletiva.

Segundo Secreto (Secreto, 2011), os debates historiográficos sobre a liberdade, principalmente com Fernando Ortiz e Gilberto Freyre atribuíram durante muito tempo um aspecto benevolente aos regimes escravistas hispânicos, devido às altas taxas de manumissões e alforrias e a grande população negra livre. Como crítica a essa visão, Tannenbaum estabeleceu em suas análises uma relação direta entre a percepção do escravo como pessoa e o acesso a liberdade, percebendo as diferentes experiências da escravidão britânica, norte americana, dinamarquesa e holandesa/francesa e hispânicoportuguesa no processo de análise da liberdade. Identificar as questões em torno da liberdade, alforria e cidadania foi um processo discutido desde a década de 1980 com Orlando Patterson, que buscava entender essa relação a partir dos conceitos de dádiva e dom e contra dom fundamentados por Marcel Mauss. George Reid Andrews e a questão dos afro-argentinos, Silvia Mallo e Lyman Johnson também realizam esse debate sobre a escravidão e liberdade.

Revista da ABPN • v. 12, n. Ed. Especial - Caderno Temático: "Africanos, escravizados, libertos biografias, imagens e experiências atlânticas" • agosto de 2020, p. $451-478$ 
A grande questão na historiografia sobre a liberdade era entender como em uma sociedade escravista se chega a um número significativo de negros/as e mulatos/as livres e sua importância e influência na formação da sociedade pós abolição. Existem duas tendências, uma que entende a alforria como estratégia senhorial, como dádiva, e outra que percebe essa relação como um processo e não como um resultado, tendo como principal expoente a micro história, que percebe o/a escravizado/a como sujeito potencialmente capaz de influenciar o processo em que está inserido (Secreto, 2011).

As práticas costumeiras e a legislação permitiram ao/a escravizado/a uma relativa flexibilidade de autonomia. A partir da década de 1980, a ação dos/as escravizados/as na busca da liberdade traz para a historiografia outra forma de se perceber as relações estabelecidas nas sociedades escravistas hispânicas, inspirados tanto nas novas correntes historiográficas da micro história e da história cultural, quanto nos movimentos sociais e pressões da sociedade para perceber os grupos subalternos a partir de outros olhares.

Partindo dessa análise, não é só a liberdade que passou a ser percebida como uma forma de contestar a escravidão, mas as lutas diárias e as autonomias como resultado desse processo, percebendo qual era o lugar social do/a escravizado/a na sociedade.

O medo e pavor instaurado em sua mente com o próximo castigo que lhe foi designado, fez com que Manzano decidisse pela fuga. Se antes tinha dúvidas e a fuga parecia um pensamento que o assombrava, mas que não parecia realmente se efetivar, agora ela era necessária. Ele temia por sua vida.

Não obstante, eu estava resolvido a jogar a sorte e a padecer com motivo. Velei até depois das onze. Aquela noite, todos se recolheram cedo, por ser noite de inverno e estava um pouco chuvosa. Selei o cavalo pela primeira vez na ida e lhe pus o freio, mas com tanto tremos que não atinava direito o que fazia. (Castro, 2015, p. 87)

Sua fuga não foi bem-sucedida. Ele foi visto, mas não tentaram impedir que ela se realizasse. "Basta-me dizer que, desde que tive conhecimento bastante da vida e até pouco depois de acabada a primeira constituição de 1812, quando me lancei a uma fuga, não acho um só dia que não esteja marcado por algum acontecimento choroso para mim" (Castro, 2015, p. 55).

\section{MANZANO, POETA}

Revista da ABPN • v. 12, n. Ed. Especial - Caderno Temático: "Africanos, escravizados, libertos biografias, imagens e experiências atlânticas” • agosto de 2020, p. $451-478$ 
Sua relação com os estudos começa desde criança, com 6 anos de idade, quando foi instruído sobre ensino religioso. "Já tinha eu seis anos quando, por ser esperto em demasia e mais do que todos, me enviaram à escola na casa de minha madrinha de batismo, Trinidad de Zayas" (Castro, 2015, p. 33). Seu talento e esperteza eram percebidos por todos ao recitar de "memória os mais compridos sermões do Frei Luis de Granada, e o numeroso grupo que visitava a casa em que nasci me ouvia declamar aos domingos" (Castro, 2015, p. 33). O acesso diferenciado de Manzano aos recursos negados a outros/as escravizados/as é atribuído por ele à bondade de sua dona, que o "tomou como um tipo de entretenimento" (Castro, 2015, p. 32), crescendo ao seu lado.

Tinha uma relação desde jovem com a poesia e como não sabia ler nem escrever, compunha muitas poesias de memória e as recitava, porque lhe era negado o direito de aprender a ler e escrever, uma relação considerada perigosa para a manutenção do status quo escravista. Diz ele que um dia estava recitando seus versos e que, quando foi pego por sua dona, apanhou; lhe puseram uma mordaça e instruíram todos para que não falassem com ele. Uma estratégia de demarcar e relembrar o lugar social ao qual Juan Francisco Manzano pertencia, que não era o da arte, nem da literatura.

Manzano publicou diversos poemas além de sua autobiografia de 1835. Publicou em 1842 uma peça de teatro chamada Zafira, deixando a escrita devido à repressão durante a Conspiração de La Escalera, responsável pelo fuzilamento de Plácido, outro poeta afrocubano. Entre seus poemas estão 'Mis Treinta años'; 'A la ciudad de Matanzas después de una larga ausencia'; 'La cocuyera'; 'A la luna'; 'La música'.

O poema 'Mis Treinta años' tem um papel essencial na relação estabelecida entre Manzano e a elite literária que patrocina seu relato. Foi ao ouvir este poema sendo recitado por Manzano que Domingo Del Monte se aproxima e percebe o potencial presente em seu discurso e a força de seu relato.

\section{MIS TREINTA AÑOS}

Cuando miro al espacio que he corrido desde la cuna hasta el presente día, tiemblo, y saludo la fortuna mía, mas de terror que de atención movido. Sorpréndeme la lucha que he podido sostener contra suerte tan impía, si tal puede llamarse la porfía de mi infelice ser, al mal nacido. Treinta años ha que conocí la tierra; Treinta años ha que en gemido estado triste infortunio por do quier me asalta. Mas nada es para mi la cruda guerra que en vano suspirar he soportado, si la calculo ¡oh Dios! con la que falta. (Manzano. Juan Francisco Mis treinta años.

Revista da ABPN • v. 12, n. Ed. Especial - Caderno Temático: “Africanos, escravizados, libertos biografias, imagens e experiências atlânticas" • agosto de 2020, p. $451-478$ 
Disponível em: http://juanfranciscomanzano.com/es/poesias, acesso em: 01 julho de 2020)

A tristeza e desilusão de Manzano se aprofundava cada vez mais, toda sua vivacidade desapareceu. Passado algum tempo se muda para Havana, para a residência de Dom Nicolás, que, segundo ele, gostava dele não como um escravo, mas como um filho. Em sua nova condição a única proibição imposta era não frequentar os ambientes urbanos para não ter contato com pessoas de maus costumes.

Sua nova rotina compreendia arrumar a casa e cuidar de todos os assuntos para que seu senhor pudesse se dedicar aos estudos onde acabou se identificando com a escrita e teve a oportunidade de aprender. Sua jornada nos estudos não se deu com o apoio de seu senhor ou com o auxílio de instituições formais, Manzano era um autodidata e aprendeu a ler e escrever copiando os textos de seu senhor.

Eu não sabia por onde começar. Não sabia cortar a pena e evitava de pegar alguma de meu senhor. Não obstante, comprei apara-penas, penas, papel muito fino, e pegava algum pedaço de papel escrito dos que meu senhor jogava fora, com sua letra, e os colocava entre folha e folha, a fim de acostumar o pulso a desenhar letras e ia copiando a forma da letra que ficava embaixo (Castro, 2015, p. 67).

$\mathrm{O}$ ato de escrever é libertador. Saber ler e escrever em uma condição de escravizado/a e principalmente no contexto cubano do início do século XIX era ameaçar a manutenção das estruturas escravistas, mesmo que em uma escala local. A tentativa de impedir seu acesso a essa forma de liberdade foi em vão e "não poucas vezes me surpreendeu na ponta da mesa que havia em um canto, me ordenando que deixasse aquele entretenimento que nada correspondia à minha classe e que achasse algo para costurar" (Castro, 2015, p. 67).

\section{RICHARD MADDEN, DOMINGOS DEL MONTE E JUAN FRANCISCO MANZANO: ARTICULAÇÕES IMPROVÁVEIS PELA ABOLIÇÃO E CONSTRUÇÃO DO ABOLICIONISMO ESPANHOL}

Segundo Schmidt-Nowara (Nowara, 2005), o processo de emancipação dos/as escravizados/as em Cuba articulou ao mesmo tempo movimentos anticoloniais e

Revista da ABPN • v. 12, n. Ed. Especial - Caderno Temático: "Africanos, escravizados, libertos biografias, imagens e experiências atlânticas” • agosto de 2020, p. $451-478$ 
antiescravistas. Após retomar Havana do domínio britânico, a coroa espanhola concedeu diversas liberdades políticas e econômicas à elite cubana, levando ao aumento considerável da escravidão e da sensação de representação política nos assuntos relacionados à ilha. Em meados de 1830, a crescente marginalização da elite criolla e as pressões do protecionismo espanhol levam a um descontentamento e ao questionamento da fidelidade à coroa.

As nações escravistas, que já sofriam pressões pelo fim do tráfico negreiro, passaram a ser pressionadas com maior força na década de 30. No caso cubano, por exemplo, as pressões inglesas encontraram na instabilidade política espanhola, causada por guerras civis, um ambiente favorável ao estabelecimento de acordos como o firmado em $1835 .^{12}$

Após o período de intensa instabilidade política, "a convocação das Cortes Gerais [...] restabeleceria o regime representativo na Espanha, recolocando em discussão pública questões ligadas à escravidão, à cidadania e à representatividade política" (Berbel, Marquese e Parron, 2009, p. 235). As aspirações por igualdade constitucional, incluindo homens de cor livre, foram novamente reprimidas pela metrópole e pelo poder do Capitão General.

O isolamento proporcionado pela ação do capitão general conseguiu conter relativamente as discussões sobre o tráfico e a abolição na ilha, porém a designação política de Cuba como zona não constitucional abriu espaço para intensos debates. $\mathrm{O}$ Segundo Império Espanhol proporcionou a manutenção do tráfico e abriu as portas para a intensificação da racialização da escravidão em Cuba. ${ }^{13}$ Entretanto, "a ausência de representação parlamentar [...], pelo princípio da cidadania racializada e pela composição estatutariamente biaxial de 'zonas constitucionais' e 'zonas não constitucionais"”

12 Tal acordo previa formas mais duras de repressão ao tráfico como intensas fiscalizações, punições severas e proibia o tráfico interprovincial. No entanto, o medo de que ideias abolicionistas circulassem na colônia era latente e a circulação dessas ideias foi altamente reprimida pelo capitão general.

${ }^{13}$ Em Cuba a instituição do Segundo Império Espanhol se fundamenta na "exclusão da representatividade colonial no parlamento peninsular, a suspensão indefinida da Constituição no ultramar, a proteção do contrabando negreiro, a concepção racializada de cidadania, um sistema tarifário protecionista para a economia de Península e a inserção quase sem barreiras da produção colonial na economia mundial de livre mercado". Criando um ambiente de insatisfação política que une setores diferentes da sociedade na discussão sobre o fim do tráfico.

BERBEL, Márcia; MARQUESE, Rafael; PARRON, Tâmis. Escravidão e política: Brasil e Cuba, 1790 1850. São Paulo, 2009, p. 262

Revista da ABPN • v. 12, n. Ed. Especial - Caderno Temático: "Africanos, escravizados, libertos biografias, imagens e experiências atlânticas” • agosto de 2020, p. $451-478$ 
(Marquese e Parron, 2011, p. 102), levou ao estabelecimento de articulações improváveis entre abolicionistas e setores ligados à escravidão.

O tráfico passou a ser visto, por abolicionistas e escravistas, como o responsável pela cisão diplomática e pela perda de direitos de altos membros da sociedade cubana, proporcionando alianças até então impensáveis. Após o período de isolamento cubano, as notícias sobre o processo de independência brasileira e a lei nacional de proibição do tráfico negreiro, acendem as fagulhas do debate sobre o tráfico de escravizados na ilha.

É nesse contexto que Manzano escreve, em um lugar de intensa repressão à circulação de ideias antiescravistas. Um homem negro escravizado letrado e poeta, transgride seu lugar social designado por uma sociedade escravista, e representa uma grande ameaça à ordem vigente. Sua obra estabelece relações com a construção do projeto abolicionista internacional, porém as constantes edições e a restrição de sua autobiografia em Cuba nos mostra como, apesar de sua resistência social e cultural, o contexto histórico da Segunda Escravidão se transformou em um cerco, que limitou o reconhecimento de Manzano como poeta e escritor.

Como parte de um dos esforços para combater o tráfico de escravos em Cuba, após o tratado de 1835 foi criado o cargo de Superintendente Geral dos Emancipados, que seria responsável por conduzir africanos traficados ilegalmente para as colônias britânicas. Richard Robert Madden foi nomeado para o cargo e como abolicionista realizou diversos esforços para o fim do tráfico. Com a intenção de conhecer melhor as condições do tráfico e da escravidão em Cuba, Madden organizou expedições a fazendas e estabeleceu contato com setores das elites insatisfeitos com a direção política que os acordos pró escravistas impuseram como a exclusão parlamentar.

Richard Robert Madden e Domingos Del Monte, foram alguns dos principais personagens nas articulações entre setores tão diversos da sociedade cubana na luta pelo fim do tráfico e estavam entre os patrocinadores e editores da obra de Juan Francisco Manzano. Del Monte também foi responsável por patrocinar outras três obras antiescravistas, após o relato de Manzano: “Petrona y Rosalía (1838), de Félix Tanco, Cecília Valdés (1839), de Cirillo Villaverde e Francisco (1839), de Anselmo Suárez y Romero - uma literatura engajada na demonstração de que o cativeiro apodrecia o relicário moral dos senhores" (Berbel, Marquese e Parron, 2009, p. 263).

Revista da ABPN • v. 12, n. Ed. Especial - Caderno Temático: "Africanos, escravizados, libertos biografias, imagens e experiências atlânticas" • agosto de 2020, p. $451-478$ 
Segundo Berbel, Marquese e Parron, Del Monte pertencia a uma família espanhola influente, que se muda para Cuba devido aos eventos de São Domingos, tendo se casado com a filha de um importante traficante de escravos. Com a perda dos direitos constitucionais na colônia, passou a criticar a permanência do contrabando, que era, segundo ele, responsável pelos entraves ao progresso cubano, criticando os mandos do Capitão General e a conivência espanhola com o tráfico. O problema da exclusão parlamentar e constitucional de Cuba acendeu a fagulha da discussão sobre o fim do tráfico, com fins de restabelecer as relações diplomáticas integrais com a Espanha. Aproveitando-se desse contexto favorável, Madden, abolicionista irlandês designado para os cargos de Cônsul e Superintendente Geral dos Emancipados em Havana, estabeleceu relações de cooperação com hacendados, aprendendo sobre o funcionamento do sistema escravista e influenciando-os a pensar a proibição do tráfico. Destas relações foram produzidos diversos materiais antiescravistas que foram apresentados na World Antislavery Convention, ${ }^{14}$ fomentando a discussão e inflamando a opinião pública.

Del Monte teve seu primeiro contato com os poemas de Manzano em um de seus encontros literários e solicitou a produção de um relato sobre sua vida como escravizado, escolhendo Manzano como representação da luta pela abolição e pelo fim do tráfico. Essa escolha não foi arbitrária e, segundo Rodriguez (Rodriguez, 1996), se deu pelo fato de que ele já era relativamente conhecido por algumas de suas publicações durante a década de 20, por seu conhecimento de literatura e por não reivindicar discursos inflamados, extremamente perigosos em uma sociedade cercada pelas tensões revolucionárias americanas.

As relações estabelecidas entre um/a escravizado/a e membros da elite não podem ser descoladas da realidade social estabelecida pelo processo de escravização de corpos negros. Apesar da luta pelo abolicionismo unir esses três personagens, suas posições e aspirações os distanciavam.

\footnotetext{
${ }^{14}$ Em 1840 foi realizada a primeira World Antislavery Convention, que uniu Grã-Bretanha, Estados Unidos e França na elaboração de projetos abolicionistas. Durante a segunda World Antislavery Convention, a anexação do Texas aos EUA acende uma possibilidade de anexação de Cuba se o Império espanhol não fosse forte o suficiente para fazer frente às pressões britânicas.

BERBEL, Márcia; MARQUESE, Rafael; PARRON, Tâmis. Escravidão e política: Brasil e Cuba, 1790 1850. São Paulo: Editora Hucitec: 2009.
}

Revista da ABPN • v. 12, n. Ed. Especial - Caderno Temático: "Africanos, escravizados, libertos biografias, imagens e experiências atlânticas” • agosto de 2020, p. $451-478$ 
Seu relato foi alvo de diversas alterações e edições em publicações posteriores. Uma das primeiras edições, denominada Poems by a Slave in the Island of Cuba, recently liberated, foi elaborada por Richard Madden. Ao editá-lo, ele se apropria do testemunho de Manzano, retirando dele qualquer especificidade e subjetividade, transformando-o em um relato generalista sobre a vida de um escravizado; sem nome, identidade, desejos, ambições, resistência e humanidade.

A utilização do relato de Manzano e a tentativa de adequar sua escrita aos anseios dos abolicionistas e literatos pode ser considerada uma segunda forma de violência e repressão, limitando novamente sua liberdade. Apesar da situação que limita sua escrita, a dupla censura imposta pela Metrópole aos cubanos e dos intelectuais cubanos a ele, Manzano cria estratégias para agradar e ao mesmo tempo subverter a ordem do discurso antiescravista (Rodriguez, 1996. p. 22). ${ }^{15}$

Sua autobiografia é produto de constantes lutas e relações de poder em uma sociedade escravista. Isso ocorre porque mesmo em meio a setores mais liberais a ideia de um/a intelectual negro/a não era e não é vista sem receios.

No momento que dispunha de espaço para relatar suas experiências de vida como escravizado, se projetar no mundo literário e ter sua escrita reconhecida, foi constantemente cerceado pela repressão de uma sociedade escravista e principalmente por seus 'incentivadores', brancos, pertencentes às elites cubanas e europeias. Del Monte e Richard Madden, patrocinadores e entusiastas da autobiografia de Manzano, eram figuras que representavam essa relação de poder presente na escrita e nas posteriores edições de seu relato.

A articulação entre setores distantes e movidos por interesses distintos no embate contra o tráfico ilegal abriu caminho para novas propostas radicais. A nomeação do novo Cônsul e Superintendente Geral dos Emancipados, David Turnbull, causou turbulências na sociedade cubana, devido a suas ideias radicais sobre como conduzir o processo de extinção do tráfico. Turnbull propõe em seu livro a ideia apresentada na primeira World Antislavery Convention: emancipar os/as africanos/as traficados/as ilegalmente, causando

\footnotetext{
${ }^{15}$ Tradução livre. De la situación que lo limita al escribir (la doble censura impuesta por la Metrópoli a los cubanos y de los intelectuales cubanos al esclavo) Manzano crea estrategias alternativas para complacer y al mismo tiempo subvertir el orden del discurso antiesciavista. RODRIGUEZ, Sonia Labrador. La intelectualidad negra en Cuba en el siglo XIX: el caso de Manzano. Revista Iberoamericana. Vol. LXII, n.174, 1996 p. 22.
}

Revista da ABPN • v. 12, n. Ed. Especial - Caderno Temático: "Africanos, escravizados, libertos biografias, imagens e experiências atlânticas” • agosto de 2020, p. $451-478$ 
um substancial abalo na demanda e na segurança das relações escravistas. Sua proposta circulou em jornais abolicionistas e, devido à sua aceitação, foi nomeado ao cargo em Havana no ano de 1840, onde deu continuidade às articulações iniciadas por Madden, contribuindo para a construção de comitês brancos e de homens de cor livres e libertos para preparar Cuba para a independência e abolição.

As discussões geradas a partir da nomeação de Turnbull levou a um intenso debate sobre como direcionar o fim do tráfico. A participação na discussão sobre o tráfico levou a uma consulta aos setores cubanos sobre o acordo britânico. Percebendo nessa consulta uma brecha para uma forma de representatividade, os esforços se voltam para tornar essa consulta extra-oficialmente obrigatória. A comissão da Junta de Fomenta produziu diversos textos em apoio à escravidão, revelando os medos que a liberdade trazia à sociedade cubana. A força do discurso da Junta de Fomenta tentava restabelecer a participação nas decisões a partir dessas consultas, sem questionar as bases do segundo império espanhol.

Outro órgão que também participou da consulta pública foi a Real Sociedad Patriótica e um membro da sociedade de Matanzas, que argumentaram contra as pressões britânicas em Cuba, no entanto se mostravam contrários a manutenção do tráfico ilegal. Outros setores salientaram a necessidade de imigração branca para a ilha devido à grande desigualdade na composição racial na sociedade sendo um risco de futuros levantes. Del Monte foi um dos que apoiou o acordo britânico baseado nas ideias de Turnbull. Em seu texto apresenta o fim do tráfico como essencial para a instauração de liberdades e da volta da representação em Cuba, porém, devido à repressão à circulação de ideias favoráveis ao abolicionismo, seu texto não teve publicação na ilha. A proposta de imigração branca foi percebida pela coroa como umas estratégias dos colonos de equilibrar as tensões raciais e iniciar um processo de independência na ilha. A solução encontrada para resolver a questão do tráfico

residia na adoção do modelo norte-americano de reprodução vegetativa dos/as escravizados/as, que garantia a expansão auto-sustentável do cativeiro sem conflitos internacionais, além de manter uma composição demográfica desfavorável a projetos independentistas (Berbel, Marquese e Parron, 2009, p. 276).

Revista da ABPN • v. 12, n. Ed. Especial - Caderno Temático: "Africanos, escravizados, libertos biografias, imagens e experiências atlânticas" • agosto de 2020, p. $451-478$ 
As iniciativas do capitão general Valdés para reprimir o tráfico são identificadas a partir de 1842, efetuando a captura de africanos/as traficados/as ilegalmente, ${ }^{16}$ de navios negreiros, proibindo a compra de navios sem a devida identificação e estimulando o bom tratamento aos/as escravizados/as em relação a alimentação, jornada de trabalho e saúde. Porém a questão do tráfico ainda causava resistência em grande parte dos/as proprietários/as e a interferência do Estado nas relações escravistas eram vistas com desconfiança. A resistência à circulação de ideias abolicionistas, pelo medo de que incentivassem revoltas e revoluções, se baseava na lembrança viva de São Domingos e nas revoltas que ocorriam na ilha desde 1830 .

\section{CONCLUSÃO}

As constantes revisões historiográficas sobre a escravidão nas Américas possibilitam resgatar uma nova forma de compreender esse processo e seus desdobramentos nas sociedades de passado escravista. Perceber o processo de escravização a partir das possibilidades de resistência e agência escrava abre novas possibilidades de estudo, como as análises autobiográficas.

As mudanças historiográficas estão atreladas a reivindicações de movimentos sociais, aqui em especial movimentos negros em suas mais plurais vertentes e a mudança na composição racial acadêmica nas universidades e institutos de pesquisa. Nesse novo contexto, novas possibilidades são exploradas, permitindo a análise histórica a partir do escravizado modificando a ideia de uma única forma de escravidão e de coisificação do escravizado. Partindo de relatos, autobiografias, ações judiciais e a história oral, podemos perceber a complexidade das relações em uma sociedade escravista.

A trajetória de Manzano e as complexas relações sociais, apresentadas em seu relato e recuperadas pela historiografia cubana, mostram ao mesmo tempo um homem negro escravizado que se mobiliza em torno de um projeto abolicionista, e, portanto, rompe com a ideia estática da escravidão, mas que ainda permanece preso as amarras da escravidão mesmo após conquistar sua liberdade.

\footnotetext{
${ }^{16}$ Cujo destino se assemelhava ao trabalho escravo.
}

Revista da ABPN • v. 12, n. Ed. Especial - Caderno Temático: "Africanos, escravizados, libertos biografias, imagens e experiências atlânticas” • agosto de 2020, p. $451-478$ 
Perceber e equilibrar as rupturas e continuidades na análise da vida de Manzano é um processo desafiador. Seu relato, publicado em Londres por Richard Madden em 1840, circulou pela Europa e foi lido na primeira World Antislavery Convention e conhecido entre os principais grupos abolicionistas do século XIX. Manzano constrói o relato de sua vida e ao mesmo tempo um relato de liberdade amplamente utilizado para sensibilizar e fortalecer o discurso abolicionista. Uma escrita cuidadosa, sensível e silenciada.

A liberdade proporcionada pela escrita abre imensas possibilidades que são constantemente rodeadas pelo medo de ser um negro, escravo e poeta desafiando os limites do escravismo. No período em que escreve sua autobiografia, Manzano conta com o apoio de uma elite criolla insatisfeita com as limitações impostas pela coroa espanhola gerando alianças impensáveis até aquele momento entre um escravo, membros da elite e abolicionistas britânicos.

O século XIX inaugura um período de intensas mudanças na sociedade cubana com o recrudescimento da escravidão e a insatisfação das elites com sua representação política no Império espanhol. São abertos espaços de discussão sobre o fim do tráfico e a abolição ao mesmo tempo em que a repressão e a censura cercavam a sociedade cubana para favorecer o escravismo. Nesse espaço de repressão e possibilidades Manzano rompe com a lógica escravista da sociedade cubana, porém sua trajetória permanece atrelada aos limites das articulações escravistas.

Em uma sociedade de passado escravista, perceber as demandas, os anseios e a luta de Manzano para ser reconhecido como poeta é essencial para transformar a visão do negro como escravo submisso, desprovido de cultura e, consequentemente, sem humanidade. Divulgar seu relato na sociedade brasileira pode colaborar para a luta contra o racismo e para a formação e resgate da identidade negra.

Trabalhar com relatos de escravizados é uma ferramenta de emancipação, de construção e fortalecimento de identidades. Relatos como este não são conhecidos pela sociedade brasileira. O discurso acadêmico ainda não consegue atingir e sensibilizar a população. A percepção e a perpetuação da estrutura racista na sociedade brasileira passam por diversos espaços; a escola, a mídia e até mesmo a família.

É necessário dialogar com os diversos saberes e adotar medidas que possam promover a emancipação da população negra no Brasil. A utilização e a divulgação da

Revista da ABPN • v. 12, n. Ed. Especial - Caderno Temático: "Africanos, escravizados, libertos biografias, imagens e experiências atlânticas" • agosto de 2020, p. $451-478$ 
autobiografia de Manzano no espaço escolar têm o potencial de identificar e problematizar os estereótipos sobre a escravidão, além de promover a construção de uma identidade negra através da valorização da história da África e cultura afro-brasileira pondo em prática a Lei 11.645/08.

\section{REFERÊNCIAS BIBLIOGRÁFICAS}

BERBEL, Márcia; MARQUESE, Rafael; PARRON, Tâmis. Escravidão e política: Brasil e Cuba, 1790 - 1850. São Paulo: Editora Hucitec: 2009.

BEZERRA, Nielson Rosa. Escravidão, biografias e a memória dos excluídos. Revista Espaço Acadêmico. n. 126, 2011, p. 136-144.

BLACKBURN, Robin. Por que segunda escravidão? In: MARQUESE, Rafael e SALLES, Ricardo (orgs). Escravidão e capitalismo histórico no século XIX: Cuba, Brasil e Estados Unidos. Rio de Janeiro: Civilização Brasileira: 2016.

CASTRO, Alex. A autobiografia do poeta-escravo. São Paulo: Hedra: 2015

CHALHOUB, Sidney. Visões de Liberdade. São Paulo: Ed. Cia. das Letras: 1988.

DOMINGUES, Petrônio. Intelectuais: conceitos e controvérsias. Revista da ABPN. v. 10, n. 25 , mar-jun 2018, p. 04-07.

EL YOUSSEF, Alain. Haitianismo em perspectiva comparativa: Brasil e Cuba séculos XVIIIXIX. $4^{\circ}$ Encontro: escravidão e liberdade no Brasil meridional. Curitiba, 2009.

FOUCAULT, Michel. A escrita de si. In: O que é um autor? Lisboa: Passagens. 1992.

GHORBAL, Karim. La política llamada del "buen tratamiento": reformismo criollo y reacción esclavista en Cuba (1789-1845). Nuevo Mundo Mundos Nuevos. Debates, 2009.

Dirāsāt Hispānicas n. ${ }^{\circ} 2,2015$. Peligros, controles y silencios atlánticos: censura y esclavitud en Cuba. . De la conceptualisation de l'esclave: Juan Francisco Manzano ou la création d'un 'personnage conceptuel' au service de l'élite créole réformiste cubaine au cours de la première moitié du XIX siècle. HISTOIRE(S) de l'Amérique latine. vol. 2, 2007.

SANTOS, Ynaê Lopes dos. La Habana Bourbônica. Reforma ilustrada e escravidão em Havana (1763-1790). Revista de Indias, LXXVII/269. Madrid, 2017

LOVEJOY, Paul E. Identidade e a miragem da etnicidade: a jornada de Mahommah Gardo Baquaqua para as Américas. Afro-Ásia, n. 27, 2002, p. 9-39.

MATTOS, Hebe. "Radicalização e cidadania no Império do Brasil". In: CARVALHO, José Murilo de e NEVES, Lúcia Bastos Pereira das (orgs.). Repensando o Brasil do Oitocentos. Rio de Janeiro: Civilização Brasileira, 2009.

Revista da ABPN • v. 12, n. Ed. Especial - Caderno Temático: "Africanos, escravizados, libertos biografias, imagens e experiências atlânticas” • agosto de 2020, p. $451-478$ 
MIRANDA, Wander Melo. A ilusão autobiográfica. In: Corpos escritos: Graciliano Ramos e Silviano Santiago. São Paulo. Ed USP, 2009.

Manzano poeta escravo: Disponível em http://juanfranciscomanzano.com/ Acesso em 29 de maio de 2020.

MARQUESE, Rafael; PARRON, Tâmis. Internacional escravista: a política da Segunda Escravidão. Revista Topoi. Vol. 12, n. 23, 2011.

MIGNOLO, Walter. Desobediência epistêmica: a opção descolonial e o significado de identidade em política. Cadernos de Letras da UFF - Dossiê Literatura, língua e identidade. n. 34, 2008.

MILLER, Marilyn. Rebeldía narrativa, resistência poética y expresión "libre” en Juan Francisco Manzano. Revista Iberoamericana. Vol. LXXI, Núm. 211, Abril-Junio 2005.

NOWARA, Christopher Schmidt. El final de la esclavitud y el final del imperio: la emancipación de los esclavos en Cuba y Puerto Rico. In: Aguirre, C. (Coord.). La abolición de la esclavitud en Hispanoamérica y Brasil. Nuevos aportes y debates historiográficos. Fundación MAPFRE. Madrid, 2005

OLIVEIRA, Rafael Domingos. Uma história social da escrita de si: autobiografias e a escravidão nas Américas. XXVIII Simpósio Nacional de História. Florianópolis, 2015.

REVEL, J. Microanálise e construção do social. In: J. REVEL (Org.). Jogos de escala: a experiência da microanálise. Rio de Janeiro: Editora FGV: 1998.

RODRIGUEZ, Sonia Labrador. La intelectualidad negra en Cuba en el siglo XIX: el caso de Manzano. Revista Iberoamericana. Vol. LXII, n.174, 1996.

SALLES, Ricardo. Segunda escravidão. Revista Tempo. Vol. 19 n. 35. 2013.

SECRETO, María Verónica. Soltando-se das mãos: liberdades dos escravos na América Espanhola. In: AZEVEDO, Cecília e RAMINELLI, Ronald. Histórias das Américas: novas perspectivas. Rio de Janeiro: Editora FGV, 2011.

SLENES, Robert. Senhores e Subalternos no Oeste Paulista. In: ALENCASTRO, Luiz Felipe de (org.). História da Vida Privada no Brasil. A Corte e a Modernidade Nacional. São Paulo: Cia das Letras, 1997

TOMICH, Dale. Through the Prism of Slavery: Labor, Capital and World Economy. Boulder Co. Rowman \& Littlefield, 2004.

. A riqueza do Império: Francisco Arango y Parreño, economia política e a segunda escravidão em Cuba. Revista de História. n. 149, 2003.

Guarulhos, n.02, 2011. A Ordem do Tempo Histórico: a Longue Durée e a Micro-História. Almanack.

Escravidão e capitalismo histórico no século XIX. In: MARQUESE, Rafael e SALLES, Ricardo (orgs). Escravidão e capitalismo histórico no século XIX: Cuba, Brasil e Estados Unidos. Rio de Janeiro: Civilização Brasileira, 2016.

.2, 2004, pág 221-240.

O Atlântico como espaço histórico. Revista Estudos Afro-Asiáticos. Ano 26, n

Revista da ABPN • v. 12, n. Ed. Especial - Caderno Temático: "Africanos,

escravizados, libertos biografias, imagens e experiências atlânticas” • agosto de 2020, p. $451-478$ 
WILLIAMS, Lorna V. The Representation of Slavery in Cuban Fiction. University of Missouri. 1994.

Recebido 03/07/2020

Aprovado em 22/07/2020

Revista da ABPN • v. 12, n. Ed. Especial - Caderno Temático: "Africanos, escravizados, libertos biografias, imagens e experiências atlânticas" • agosto de 2020, p. $451-478$ 